\title{
Are Crab-collectors in Mangroves of Northern Brazil (PA) Optimal Foragers?
}

\author{
Ole Thies Albrecht ${ }^{1} \cdot$ Marion Glaser $^{1,2} \cdot$ Martin Zimmer $^{1,3,4}$ (D) \\ Received: 2 November 2020 / Accepted: 13 August 2021 / Published online: 10 September 2021 \\ (C) The Author(s) 2021
}

\begin{abstract}
Intensive harvesting of the mangrove crab Ucides cordatus provides subsistence for food and main or additional income to many inhabitants of mangrove areas in Northern Brazil. In order to better understand the spatial patterns of use of this natural resource as basis for sustainable resource-management, we used a combination of GPS-tracking, field observations, semi-structured interviews and participatory mapping with crab-collectors. We quantified daily working hours, traveling distance and time to, as well as collecting time inside, the patches where crabs are collected. Based on preliminary findings for three different types of transportation to the fishing grounds, we conclude that crab-collectors in our study area act in accordance with the central place optimal foraging concept in that they invest more time in traveling to areas with higher catch. We hold these findings will prove relevant for sustainably managing the use of mangrove crabs as natural resource. The parallel occurrence of different collectingbehaviours possibly releases pressure from crab stocks in the potentially depleting fishing grounds adjacent to villages, and thus, may render crab-collecting in these areas more sustainable. Detailed studies are needed to quantify the catch from different mangrove areas and to make these data useful for the sustainable management of natural resource-exploitation in mangroves.
\end{abstract}

Keywords Crab fisheries $\cdot$ Ucides cordatus $\cdot$ Spatial patterns $\cdot$ Sustainable resource-use

\section{Introduction}

The mangrove ecosystem of Pará State, Northeast Brazil, supplies multiple human communities along the coast with a variety of ecosystem services, goods and benefits. More than 80 $\%$ of the rural households gain resources for their livelihood directly from the mangrove forest; $43 \%$ of all households collect the mangrove crab Ucides cordatus for subsistence, or sell it for their main or additional income (Furtado 1990; Glaser 2003; Glaser et al. 2010). Therefore, the exploitation of

This article belongs to the Topical Collection: Coastal Wetlands.

Martin Zimmer

martin.zimmer@leibniz-zmt.de

1 Leibniz Centre for Tropical Marine Research, ZMT, Fahrenheitstr. 6, D-28359 Bremen, Germany

2 Institute for Geography, University of Bremen, Faculty 8, 28359 Bremen, Germany

3 Faculty 2 Biology/Chemistry, University of Bremen, 28359 Bremen, Germany

4 IUCN SSC Mangrove Specialist Group, London, UK this natural resource is a major key component for socioeconomic stability and social sustainability for low-income classes in the region (Glaser 2003; Glaser and Diele 2004; Diele et al. 2010). Given the importance of this resource for the surrounding communities, a detailed understanding of harvesting practices is essential for implementing long-term sustainable management.

Professional crab collectors capture the large, semiterrestrial crab in its burrow by hand and sell it alive or for processing, earning about the Brazilian minimum wage (Glaser 2003). Crab-collecting grounds are either reached from the landside by walking, by bicycle or by public bus, or canoes or motor vessels are used to access crab-collecting grounds adjacent to the sea. Because of its importance for the environment and the rural communities, many studies focused on the biology of $U$. cordatus (e.g., Pinheiro et al. 2005; Nordhaus and Wolff 2007). Others examine the livelihood of people involved in crab fisheries (Glaser and Diele 2004; Diele et al. 2005; Alves et al. 2005). While these provide the biological and societal baseline for crab-collecting in this area, only very little is known about the spatial patterns of crabcollecting by local crab-collectors and their relation to resource availability (Araujo 2006; Oliveira 2015) which, in 
turn, is pivotal to understanding the distribution of resources and their use, and to managing them.

To predict and effectively manage a social-ecological system, it is crucial to understand the motivations and behaviors of its actors. The $U$. cordatus fishery has the potential to contribute to the sustainable development of the coastal region of Pará. It creates a steady income and supports a viable livelihood for the rural poor without using environmentally destructive methods such as (illegal) logging, slash-and-burn agriculture or cattle ranching, all of which are common practices in the North Brazilian state of Pará (Fernandes et al. 2018). In contrast to the latter, while extracting biomass, crab-fishery is regulated with regard to minimum capture size of individual crabs and through closures during the reproductive period. Hence, the environmental impacts seem to be low. In order to develop a baseline for understanding the potential impact of crab fisheries, we analysed spatial patterns of crabcollecting in the Extractive Reserve (RESEX) Caeté-Taperaçu of the Ajuruteua peninsula near Bragança, Pará.

Consumers searching for food items in a heterogeneous environment have to make decisions on where to search and for how long. For consumers with an explicitly defined home site, such as crab-collectors, traveling some distance backand-forth from and to their home for collecting food, the concept of central place foraging (Orians and Pearson 1979) applies. In this case, the total time spent foraging (the time away from home) can be split into time for traveling between the home site and the patch, searching for food items inside the patch, and handling the food item. We hypothesize that crabcollectors follow the predictions of the optimal foraging concept for minimizing costs (e.g., time) and maximizing gains (here, number or size of crabs) of collecting trips in a heterogeneous environment of patches with varying densities and sizes of crabs (MacArthur and Pianka 1966; Pyke et al. 1977). This central concept of ecological theory has been successfully used to explain various aspects of food choice and foraging behaviour. Thus, food choice or time spent for traveling to patches versus time spent searching for and collecting food items should depend on the quality of food items (size or energy content) and their availability (and abundance) in different patches.

In the context of crab-collecting in mangrove forests, we derived several hypotheses:

(1) The further the crab-collectors have to travel between fishing grounds and home, the longer they will stay in the patch collecting crabs, and the more crabs they will collect and carry home.

(2) The more abundant (2a: quantity) or larger (2b: quality) the crabs in a given fishing ground are, the more traveling time the crab-collectors are willing to invest in reaching the patch.
(3) The more abundant (2a) the crabs are, the more selective will crab-collectors be with respect to the body size (measure of quality: 2b) of crabs; however, when the searching time for individual crabs increases, crabcollectors will become less selective and will continue adding crabs to their catch irrespective of their size.

\section{Methods}

\section{Study Area}

This study focuses on the coastal strip of mangrove forests at the Caeté Estuary of the Ajuruteua peninsula, $200 \mathrm{~km}$ east of the Pará state capital Belém, and $300 \mathrm{~km}$ southeast of the Amazon delta. Part of the study area is protected and declared as the Caeté-Taperaçu Reserva Extravista (RESEX, "Extractive Reserve"). This locally run and controlled category of protected areas allows local users to extract selected resources under administration by a supervisory board.

Two villages (Caratateua and Treme (Fig. 1)) were chosen as study locations based on previous evidence of high crabcollecting activity (Araújo 2006). The two villages are comparable in size, infrastructure, market structure and in their participation in crab-collecting. The villages are five kilometers apart and located on the southern bank of the Caeté estuary, just outside the mangrove area. Both their harbors are home to some smaller vessels (barco) and dozens of canoes. In 2003, 250 crab-collectors lived in Caratateua and 300 in Treme (Araújo 2006). The crab-collectors in the study area commonly capture crabs from their burrows by hand (braceamento method), using protective sleeves and gloves. In this case, handling time is essentially independent of crab size. Searching time, however, is negatively proportional to crab abundance (or dependent on the size spectrum in case of selective collecting). Traveling time is a function of distance that, in turn, drives the choice of transportation.

\section{GPS-tracking of Movements of Crab-collectors}

In this preliminary study, crab-collectors were selected through contacting spokespersons of the villages, as well as academics of the Universidade Federal do Pará (UFPA) in Bragança with local fieldwork experience, who then suggested individuals for this study. We equipped selected crabcollectors $(\mathrm{N}=5$ in each village) with GPS-trackers during their daily collecting campaigns in order to map their movements towards and inside fishing grounds. Two types of GPStrackers were used, Mobile Action I-Got U USB GPS Tracker (120) (MobileAction) and the GT-750FL Bluetooth GPS Receiver (Canmore Electronics Co.). For the sake of ease- 


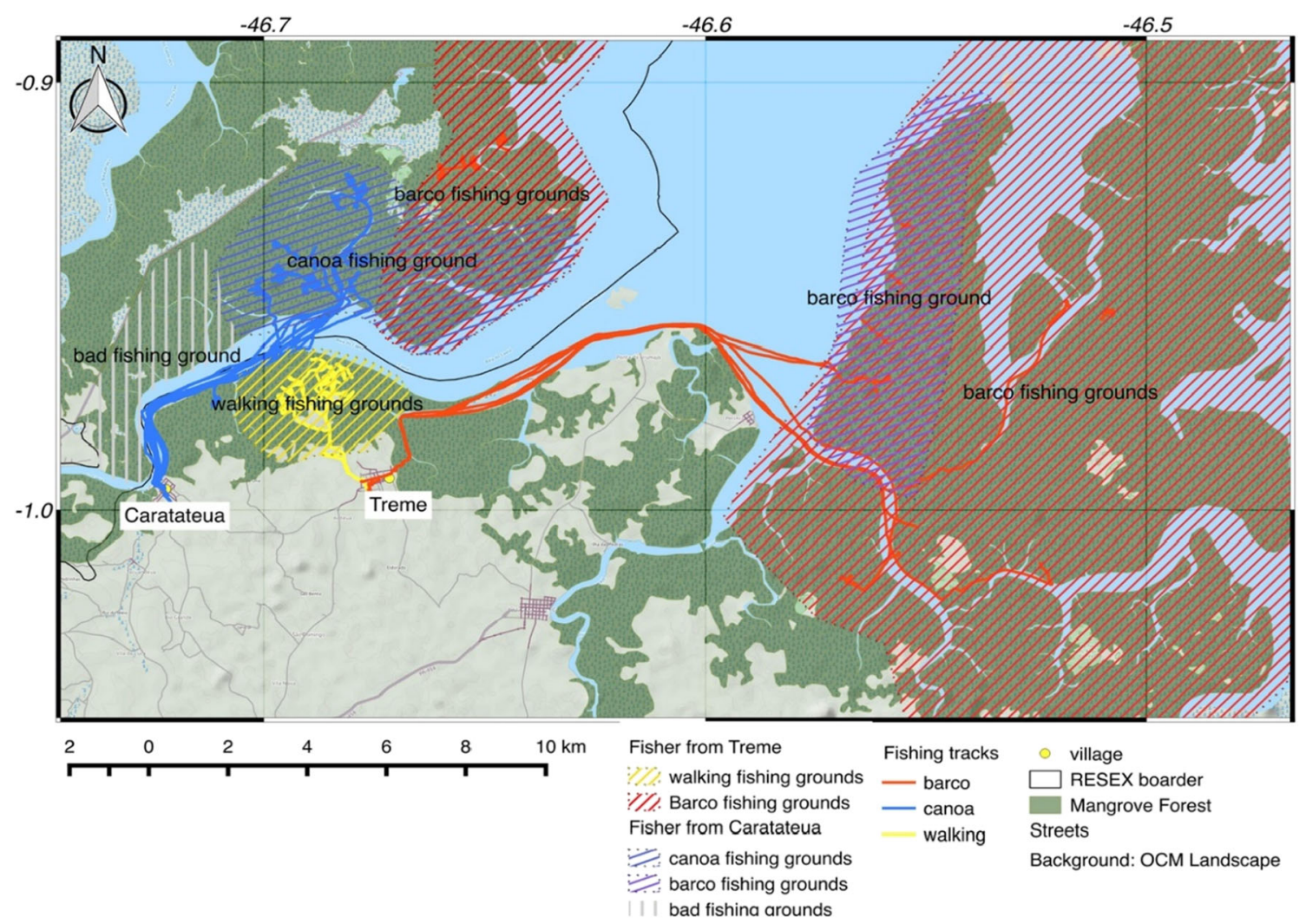

Fig. 1 Location of fishing grounds for different transportation types, based on participatory mapping events with crab-collectors in Caratateua and Treme (hatched areas), and as confirmed by satellite tracks (solid lines) of movements of crab-collectors

of-use, both models only have one button which turns the device on or off. GPS-trackers were set to $\log$ position at five-second intervals. Participating crab-collectors were able to use the GPS-tracker for up to two working days, before the battery had to be recharged. The tracker was then collected and a spreadsheet with basic daily information was filled out upon interviewing the crab-collector. Detailed insight into collecting procedures that could not be gained from GPS data was obtained by joining crab-collectors during one collecting campaign. This yielded $16 \mathrm{~h}$ of observation for groundtruthing and recording crab collectors' statements on activities associated with recorded GPS-patterns.

The crab-collectors were asked to personally carry the GPS-tracker (see above) during the entire working day, from leaving home to arriving back home after collecting crabs inside the mangrove forests. A small waterproof plastic box was provided for storing the tracker during the working day. The best option proved to be carrying the GPS under their hat or cap, because this is the only body part which has no or only little contact with mud and water during crab-collecting, and it thus will not encrust in mud and will provide the best satellite connection due to its exposed position. Most crab-collectors found the container cumbersome and stored the tracker only in plastic bags, thus causing malfunction of some GPS-trackers.

All data analyses were done with open-source programs, enabling easy and low budget reproduction of the methods.
QGIS 2.6.1 was used to perform spatial analyses. R Studio version 0.98 was used for statistical analyses of traveling time and distance, as well as collecting time on site, and for calculating Spearman correlations (not requiring linear relationships between variables) among all variables derived from GPS data. Oneway ANOVA, with type of transportation as factor, was used to analyse track length, speed, traveling and collecting (= searching + handling) times, and size of collecting grounds. A total of 21 working days was recorded for crab-collectors from Treme and 16 working days for crabcollectors from Caratateua, resulting in a total of 181,473 recorded data points.

\section{Results}

According to GPS-tracking and semi-structured interviews with participatory mapping (Fig. 1), crab-collectors use crabcollecting grounds repeatedly with an interval of about 15 days between campaigns, corresponding with statements made by crab-collectors in the 1997-2005 period (M. Glaser, personal observation). For distinguishing among crab-collecting grounds, crab-collectors mark and name streams. Marks can be as simple as machete cuts in the bark of trees or plastic objects like bottles or old toys. Names given to small creeks differ across villages, indicating traditional 
local landscape recognition rather than common agreement among villages.

Crab-collectors in the two villages studied can be categorized by how they reach the crab-collecting ground: by walking, taking a canoe, or traveling in a group of up to ten on a small boat (barco). Outbound canoe and barco collectiontrips are launched during outgoing tide, taking advantage of the current. Crab-collectors then spend the low tide period in the mangrove forest and travel back to their harbors with the incoming tidal current, about $6 \mathrm{~h}$ later, thus again making use of the incoming tidal current. Mangrove patches adjacent to the village were reached by walking, being less tidedependent than traveling by canoe or barco.

Travel distance (Fig. 2a) increased with motorization. Shortest travel distances back-and-forth were observed with crab-collectors walking into their fishing grounds $(6 \pm 3 \mathrm{~km}$; mean \pm standard deviation). Clearly longer distances $(\mathrm{p}<$ $0.001)$ were covered, when a canoe with outboard motor was used $(20 \pm 14 \mathrm{~km})$, and even longer distances $(\mathrm{p}<$ $0.001)$ were covered when a barco was shared by several crab-collectors of the same village $(36 \pm 20 \mathrm{~km})$.

Crab-collectors using a canoe walked longer distances $(7 \pm$ $1 \mathrm{~km}$ ) inside the mangrove forest than those using other types of transportation $(4 \pm 2 \mathrm{~km}$ for both walking and barco) $(\mathrm{p}=$ 0.004; Fig. 2b). However, the time spent inside the mangrove forest (collecting time $=$ searching time + handling time) was independent of transportation type, ranging on average from 5.5 to $6.5 \mathrm{~h}$, roughly coinciding with the time window of low tide ( $p=0.49$; Fig. $2 \mathrm{c}$ ). The time spent traveling was remarkably longer by barco $(8 \mathrm{~h})$ than by canoe $(2.5 \mathrm{~h})$ or by foot $(1 \mathrm{~h})(\mathrm{p}<0.001)$, resulting in a working day of $13 \mathrm{~h}$ when using a barco versus $9 \mathrm{~h}$ when traveling by canoe versus $7 \mathrm{~h}$ when walking (Fig. 2d).

Crab-collectors walking into their crab-collecting grounds utilized a wide area for collecting crabs, whereas those using a canoe were mainly collecting in areas adjacent to the sea. Crab-collectors sharing a barco with some ten others walked further into the mangrove forests than canoe-based fishers. Based on the lengths of individual tracks of crab-collectors inside the mangrove forest, and assuming a $10 \mathrm{~m}$ corridor for capturing crabs along the track (pers. observation during field work), we estimated the area of individual fishing grounds (Fig. 2e). Overall, the size of these areas was independent of the transportation type (i.e., we found no significant differences among transportation types: $p=0.45$ ), being on average slightly larger than 2 ha per crab-collector.

The GPS-tracking revealed a typical pattern of movement inside the mangrove forest, which we will henceforth call "treetop-track". This pattern (Fig. 3) was observed 24 times, always for barco and canoe trips. Typically, crab-collectors enter the mangrove forest through streams and creeks until they find a suitable place for anchoring the vessel. They then spread from the vessel for a maximum of several hundred meters and set up a primitive base location (B in Fig. 3), where food, water and the catch is stored. The individual crabcollector starts collecting directly onwards by moving deeper into the mangrove forest. When the collection sack is half filled, normally not further then $200 \mathrm{~m}$ from the base, the crab-collector returns slowly to the base, while still collecting crabs. After one to two hours, the crab-collector reaches the base again and empties the crabs into a bigger mesh sack to then move off again for continued crab collection.

In the case of walking trips, crab-collectors rather applied a roundtrip through the crab-collecting ground, and the treetoptrack was observed only for half the recorded walking trips. As the entire catch needs to be carried home anyway, it might not pay off to divert the sampling trip from a roundtrip into a treetop-track and thus to walk the same trail twice and, consequently, cover a smaller area while sampling.

\section{Discussion}

Within the area of the present study, Oliveira (2015) observed a crab density of $1.3 \mathrm{~m}^{-2}$ in mangrove stands that were considered difficult to access (mostly coinciding with collecting grounds reached by barco in this study), and $1.1 \mathrm{~m}^{-2}$ in areas of easy access (coinciding with collecting grounds reached by canoe or by walking). Diele et al. (2005) had determined a mean density of $1.7 \mathrm{~m}^{-2}$, with an average carapace width of $66 \mathrm{~mm}$ for male (commercially relevant) crabs, about 10 years earlier. A similar density of $1.2 U$. cordatus per $\mathrm{m}^{2}$ was described for the estuary of the São Francisco River (NE Brazil) by Santos et al. (2018). Much higher densities of $6 \mathrm{~m}^{-2}$ were found at the Coroa do Sapo Island of São Paulo state (Pinheiro et al. 2018). Santos et al. (2018) distinguished between crabs of commercially valuable size (based on burrow openings $>$ $51 \mathrm{~mm}$, representing a carapace width of $>60 \mathrm{~mm} ; \geq 65 \mathrm{~mm}$ carapace width, according to Diele et al. 2005), reaching a density of $0.8 \mathrm{~m}^{-2}$, and those of smaller size, reaching only 0.4 ind. $\mathrm{m}^{-2}$. The opposite size distribution characterized the $U$. cordatus population at Paranaguá Bay in southern Brazil, where crabs of commercial value reached densities of $0.9 \mathrm{~m}^{-}$ ${ }^{2}$, while smaller crabs were more abundant $\left(1.4\right.$ ind. $\mathrm{m}^{-2}$ ) (Sandrini-Neto and Lana 2012). There, crab abundance exhibited high small-scale variability, and the same was observed for the distribution of crabs of different sizes in our study area by Piou et al. (2009). Crabs in stands of Avicennia germinans and Laguncularia racemosa were significantly smaller than those in stands of Rhizophora mangle, possibly due to competitive exclusion of small crabs from Rhizophora stands by large crabs (Piou et al. 2009). Along a similar line, the abundance of small crabs below commercial value decreased with decreasing sediment grain size at Paranaguá Bay (SandriniNeto and Lana 2012): the sediment in Rhizophora stands is usually much finer than in stands of the other species of our 
Fig. 2 Effect of transportation type on (a) traveling distance towards, and (b) track length inside the fishing ground; (c) traveling time towards, (d) collecting time inside, and (e) size of fishing grounds
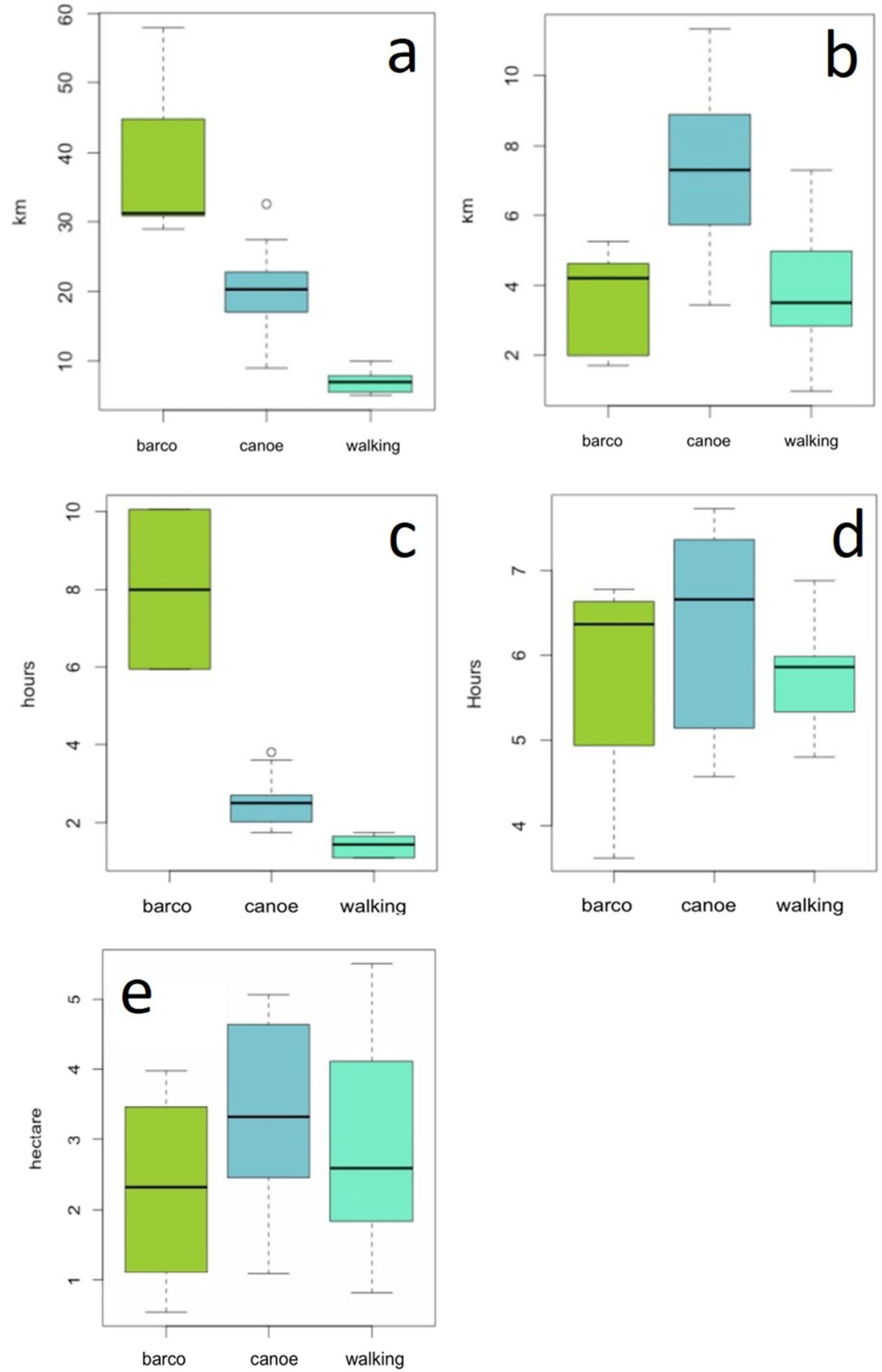

study region (M. Zimmer, pers. obs.), rendering walking in Rhizophora stands much more challenging, but obviously more beneficial in terms of abundance and size of commercially valuable crabs. By contrast, Kassuga and Masunari (2015) did not find any variation in the abundance of juvenile $U$. cordatus along a landward gradient from the riverbank (likely following a change in mangrove species dominance). Instead, burrows of adult crab seemed to also host juveniles up to $1 \mathrm{~cm}$ carapace width. Comparing the distribution of fishing grounds derived from this study with vegetation maps (Mehlig et al. 2010) and our own knowledge of the study area, vessel-based crab-collectors followed during this study mostly visited Rhizophora stands. However, those stands directly on the northern border of the Caeté estuary (see Fig. 1) are mostly dominated by Avicennia and are home to smaller crabs (cf. Oliveira 2015).

Compared to previous data (Araujo 2006; Oliveira 2015), the present study did not detect a spatial shift of crabcollecting grounds. Similarly, the temporal pattern of fortnightly return to the same crab-collecting grounds evident from this study had already been observed between 2000 and 2010 (M. Glaser, pers. obs.). The same mangrove areas adjacent to the villages that were used by crab-collectors during this survey had been assumed to bear declining stocks of 

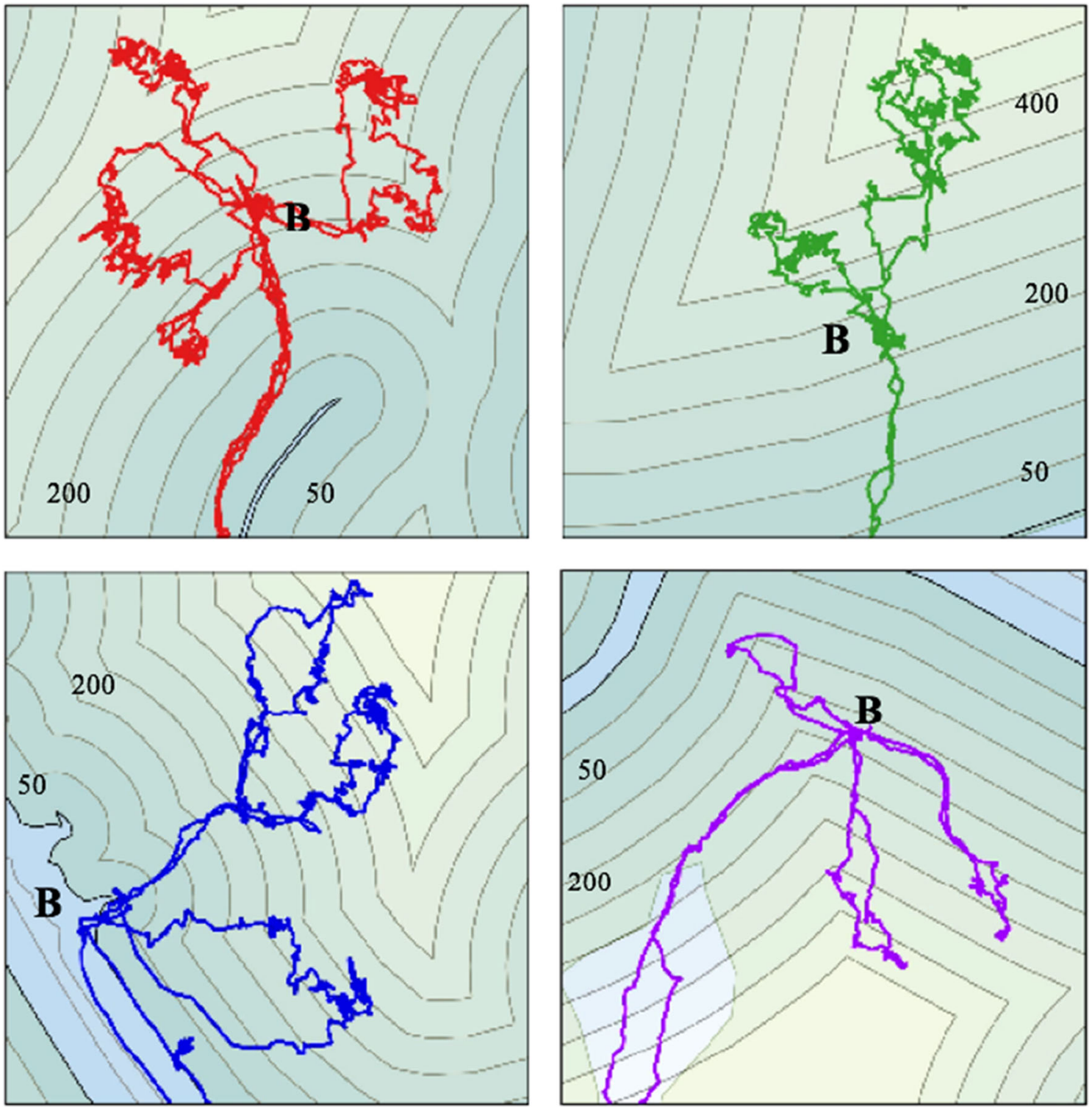

Fig. 3 Selected GPS tracks showing typical movement patterns of crab-collectors. B: Base location; 50, 200: Distance to coastline (m). Red and blue line: canoe-based crab fishing; green line: barco-based crab fishing; purple line: foot-based crab fishing

crabs already by Krause et al. (2001). However, almost 20 years later, these very same stocks still seem to support crabcollectors that reach their crab-collecting grounds by foot.

The crab-collecting grounds of the villages Caratateua and Treme showed no overlap in our study, and those crabcollectors from Caratateua followed by us solely went by canoe, whereas the crab-collectors we followed from Treme either walked into adjacent mangrove forests or used the barco to cover large distances. Differences between the patterns arising from using the canoe vs. the barco, hence, might be driven by different practices in these two villages. Across all collecting campaigns from both villages, our descriptors of the crab-collectors' movements correlated with each other (Fig. 4). Expectedly, travel distance was significantly correlated with travel time $(r=0.93 ; p<0.001)$ and travel speed $(r$
$=0.89 ; \mathrm{p}<0.001)$. Travel time and travel speed were positively correlated with each other $(r=0.86 ; \mathrm{p}<0.001)$, indicating that traveling with the canoe or barco was faster and covered a longer distance than traveling by walking. The distance walked inside the mangroves ("track length") increased with increasing speed inside the mangroves ("speed on track") $(r=0.93 ; p<0.001)$, suggesting that either (i) the crabcollectors walk faster in order to be able to cover a larger area (in an area that they know to be inhabited by less or smaller crabs of lower value), or (ii) low capture success in a given area allows for moving faster (less handling time, more searching time) and thus covering a larger area. The outcome of both would be larger collecting grounds in areas with low crab abundance or small crab size. This, however, is not reflected in the estimated collecting ground sizes (Fig. 2). 
According to Krause et al. (2001), mangrove patches adjacent to the village had experienced declining crab abundance. Investing in the use of a vessel (canoe or barco) instead of walking into the mangrove next to the village might reflect the need for compensating for the reduced catch in these patches. At the same time, this strategy will result in reducing crabcollecting pressure on these nearby mangrove patches. On the other hand, going out by vessel requires much more time than collecting campaigns on foot. According to simple cost:benefit calculations, this behavior will only pay, if the gain from these longer campaigns is markedly higher than that of foot-based collecting campaigns. According to the findings by Oliveira (2015), crabs in collecting grounds reached by canoe are smaller (ca. 69-75 mm carapace width; median = $70 \mathrm{~mm}$ ) than in collecting grounds reached by barco (ca. 73$75 \mathrm{~mm} ; \mathrm{M}=73 \mathrm{~mm}$ ); no such data are available for collecting grounds reached by walking. This difference seems negligible, but the disproportionate growth of claws of male crabs relative to carapace width (Buck et al. 2003; Dalabona et al. 2005; Pinheiro and Hattori 2006) makes it likely that an average difference of $3 \mathrm{~mm}$ carapace width will result in a difference in claw weight that renders the larger crab a more attractive target for crab-collectors. Thus, crabs from the collecting grounds reached by barco probably have a higher value for the market of crab claws than those from the collecting grounds reached by canoe.

According to the optimal foraging concept (sensu McArthur and Pianka 1966; Charnov 1976; Orians and Pearson 1979), we

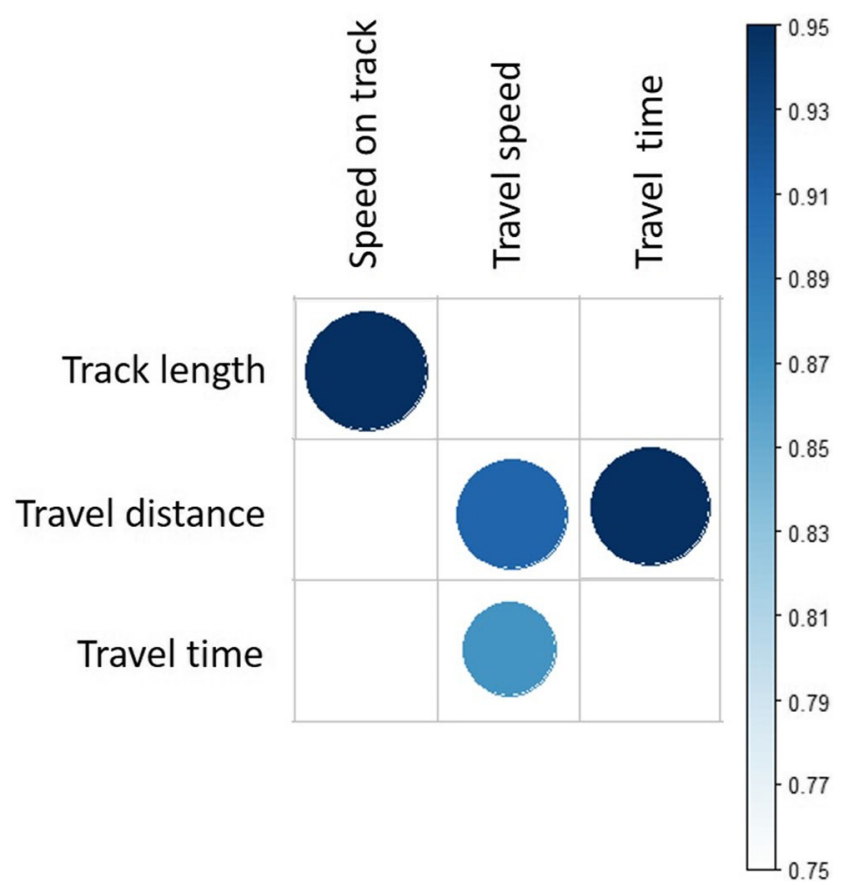

Fig. 4 Spearman correlations among descriptors of crab-collectors' movements during collecting campaigns. Only significant $(\alpha=0.05)$ correlations are depicted; size and colour of the circles reflect the magnitude of the correlation coefficient expected crab-collectors to spend more time in the mangrove forests and collect more crabs when traveling by barco (longer traveling time) than when traveling by canoe or when walking into the mangrove forests (hypothesis 1). Contrasting this hypothesis, collecting time on site was the same in all three categories, probably determined by the duration of the low tide. However, crab-collectors moved over longer distances (within the same time frame) in patches reached by canoe than in the other categories (Fig. 2). We hypothesize that crabcollectors in these patches spent more time searching (large) crabs than they spent actually handling (capturing) crabs, in order to maximize the value of their catch. However, they would have to walk longer distances (i.e., faster, given the similar time spent inside the mangroves for all crab-collectors: see correlation, Fig. 4) while disregarding small crabs and focusing solely on large crabs (without spending more time on site: Fig. 2) (hypothesis 3). Admittedly, our data cannot vigorously test this hypothesis, as we did not receive exact information on the number of crabs collected or on their size. Detailed studies taking this information explicitly into account are needed. However, Krause et al. (2001) stressed declining stocks of crabs in mangrove areas adjacent to the villages, i.e., in walking distance. Araujo (2006) and Oliveira (2015) both report that easily accessible mangrove areas (e.g., those adjacent to villages) are home to smaller crabs.

Even though crab-collectors did not stay longer on site after having travelled for a longer time by barco than by canoe or by foot, we hypothesize that the catch they will carry home will consist of more numerous and larger crabs (following hypotheses 1 and 2), but this assumption requires vigorous testing by future studies. The total amount of crabs collected during an individual collecting campaign obviously depends on how much the crab-collector can carry. By walking, only one big sack (approx. 200 crabs; $>40 \mathrm{~kg}$ ) can be carried back home. The capacity of a canoe or barco for collected crabs does essentially not limit the weight of the catch to be transported back home. It is rather the time window between outgoing and incoming tides and the duration of the low tide inside the patch that limits total collecting time, and thus, the catch. The tree-top track (Fig. 3) exhibited during all trips by canoe and barco, but during only half the trips by foot, supports this catch efficiency by allowing to carry small catches to a central base location repeatedly, whereas crab-collectors traveling by foot cannot collect more than they can carry in one go. Those who reach their collecting grounds by walking do not need to employ the treetop collection pattern, as they can only carry one sack home anyway. By rather performing roundtrips, they optimize the area sampled per trip through avoiding walking the same trail twice (in opposite direction). Hence, by walking about only half the distance of crabcollectors traveling by canoe, they cover essentially the same sampling area (Fig. 2) without necessarily having to move faster (despite the above correlation: Fig. 4). 
According to previous studies (Oliveira 2015), crabs in collecting grounds reached by canoe are smaller than those in collecting grounds reached by barco, corroborating Hypothesis 2. Possibly, this difference in crab size even explains the shorter searching distance in patches reached by barco than by canoe, because the crabs in the former are generally larger: within the same time and by walking shorter distances (Fig. 2), more large crabs can be collected. Future detailed studies are needed to quantify the catch and its quality (size of crabs) for individual crab-collectors in the context of transportation and fishing ground location.

\section{Conclusions}

While trying to better understand spatial patterns of crabcollecting in extensive mangrove areas in Northern Brazil, we unintendedly discovered a behavior that appears to follow the predictions of the central place optimal foraging concept. It appears reasonable to assume that investing in traveling for a long time by canoe or barco will pay only, if the catch rate (number of crabs per time unit) is markedly higher in areas reached by barco or canoe, where crab-collectors can spend more time handling, rather than searching for, crabs. This conclusion was backed by statements of all interviewed fishers. The optimal foraging concept predicts that time spent on site should increase with traveling time. However, using the currents of outgoing and incoming tides for traveling towards collecting grounds and back home, respectively, restricts the time that can be spent within the mangrove forests.

Whereas quantitative evidence to fully support our hypotheses is still lacking, and further detailed studies are needed, we hold that understanding the crab-collectors' behavior in smallscale subsistence crab-collecting in the context of spatial patterns of crab abundance and size distribution will prove relevant for sustainably managing the use of this natural resource. The parallel occurrence of different behaviours, as observed in the present study, reflects either (i) alternative strategies of individual crab-collectors (i.e., individual crab-collectors always use the same transportation) or (ii) the strategy of individual crab-collectors to alternately follow different tactics (i.e., shifting among walking and using a canoe or a barco). Such alternative behaviours can only co-exist in the long run, when all strategies or tactics overall yield approximately the same net energy gain, i.e., when the cost:benefit ratio is constant. The resulting spatial spreading of crab-collecting grounds potentially releases pressure from crab stocks in the collecting grounds adjacent to villages, and thus, may render crab-collecting in these areas more sustainable. However, shifting collecting pressure to remoter areas through improved transportation technology may only be a postponement of sustainability issues, as additional crab-collectors may enter local collecting grounds adjacent to villages. Additional research is needed to examine the range of possible future scenarios that are emerging, and how these changes in resource-use can be managed sustainably.

Acknowledgements We are grateful to the participating crab-collectors of Caratateua and Treme, the assisting students of UFPA, Karoll Miyuri and Manoel Elielson Ramos Cardoso, and Professor Roberta Sá Leitão Barboza for outstanding field work supervision.

Authors' Contributions MZ, MG \& OTA developed the research; OTA performed the field work and collected the data; OTA \& MZ analysed the data; MZ, OTA \& MG wrote the manuscript.

Funding Open Access funding enabled and organized by Projekt DEAL. No external funding was obtained; all financial support is based on internal budgets of the scientist's research institute.

Data Availability The datasets used and analysed during the current study are available from the corresponding author on reasonable request.

\section{Declarations}

Conflict of Interest The authors declare no conflicts of interest.

Ethics Approval Interactions with crab-collectors had been reviewed and approved internally; no information about interviewees are contained in the manuscript.

Consent to Participate All interviewees gave their consent to participating and did so voluntarily.

Consent for Publication Everybody entitled so gave their consent for this research being published.

Open Access This article is licensed under a Creative Commons Attribution 4.0 International License, which permits use, sharing, adaptation, distribution and reproduction in any medium or format, as long as you give appropriate credit to the original author(s) and the source, provide a link to the Creative Commons licence, and indicate if changes were made. The images or other third party material in this article are included in the article's Creative Commons licence, unless indicated otherwise in a credit line to the material. If material is not included in the article's Creative Commons licence and your intended use is not permitted by statutory regulation or exceeds the permitted use, you will need to obtain permission directly from the copyright holder. To view a copy of this licence, visit http://creativecommons.org/licenses/by/4.0/.

\section{References}

Alves RRN, Nishida AK, Hernández MIM (2005) Environmental perception of gatherers of the crab 'caranguejo-uçá' (Ucides cordatus, Decapoda, Brachyura) affecting their collection attitudes. Journal of Ethnobiology and Ethnomedicine 1:10

Araujo AR (2006) Fishery statistics and commercialization of the mangrove crab, Ucides cordatus (L.), in Bragança - Pará - Brazil. Diploma Thesis University of Bremen. 176pp

Buck TL, Breed GA, Pennings SC, Chase ME, Zimmer M, Carefoot TH (2003) Diet choice in an omnivorous salt marsh crab: different food 
types, body size and habitat complexity. Journal of Experimental Marine Biology and Ecology 292:103-116

Charnov EL (1976) Optimal foraging, the marginal value theorem. Theoretical Population Biology 9:129-136

Dalabona G, de Loyola e Silva J, Pinheiro MAA (2005) Size at morphological maturity of Ucides cordatus (Linnaeus 1763) (Brahyura, Ocypodidae) in the Laranjeiras Bay, Southern Brazil. Brazilian Archives of Biology and Technology 48:139-145

Diele K, Koch V, Saint-Paul U (2005) Population structure, catch composition and CPUE of the artisanally harvested mangrove crab Ucides cordatus (Ocypodidae) in the Caeté estuary, North Brazil: Indications for overfishing? Aquatic Living Resources 18:169-178

Diele K, Araujo A, Glaser M, Salzmann U (2010) Artisanal fishery of the Mangrove Crab Ucides cordatus (Ocypodidae) and First Steps towards a Successful Co-Management in Bragança, N-Brazil. In: Saint Paul U, Schneider H (eds) Mangrove dynamics and management in North Brazil. Springer, Heidelberg, pp 287-298

Fernandes MEB, Oliverira FP, Eyzaguirre IAL (2018) Mangroves on the Brazilian Amazon Coast: Uses and Rehabilitation. In: MakowskiC, Finkl CW (eds). Threats to Mangrove Forests: Hazards, Vulnerability, and Management. Springer, pp 621-636

Furtado LG (1990) Características gerais e problemas da pesca Amazônica no Pará. Bol Mus Para Emílio Goeldi Sér Antropol 6: $41-93$

Glaser M (2003) Ecosystem, local economy and social sustainability: A case study of Caeté estuary, North Brazil. Wetlands Ecology and Management 11(4):265-272

Glaser M, Diele K (2004) Asymmetric Outcomes: Assessing the biological, economic and social sustainability of a mangrove crab fishery, Ucides cordatus (Ocypodidae), in North Brazil. Ecological Economics 49(3):361-373

Glaser M, Krause G, Oliveira R, Fontalvo-Herazo M (2010) Mangroves and people: A social-ecological system. mangrove dynamics and management in North Brazil. U. Saint-Paul and H. Schneider. Springer, Berlin, pp 307-351

Kassuga AD, Masunari S (2015) Spatial distribution of juveniles of the mangrove crab Ucides cordatus (Linnaeus, 1763) (Crustacea, Brachyura, Ucididae) from Guaratuba Bay, southern Brazil. PanAmerican Journal of Aquatic Sciences 10:222-229

Krause G, Schories D, Glaser M, Diele K (2001) Spatial patterns of mangrove eosystems: the Bragantinian mangroves of Northern Brazil (Bragança, Pará). Ecotropica 7:936-107

MacArthur RH, Pianka ER (1966) On optimal use of a patchy environment. The American Naturalist 100:603-609

Mehlig U, Menezes MPM, Reise A, Schories D, Medina E (2010) Mangrove Vegetation of the Caete' Estuary. In: Saint-Paul U,
Schneider H (eds) Mangrove Dynamics and Management in North Brazil. Springer, Berlin, pp 71-107

Nordhaus I, Wolff M (2007) Feeding ecology of the mangrove crab Ucides cordatus (Ocypodidae): food choice, food quality and assimilation efficiency. Marine Biology 151:1665-1681

Oliveira FPD (2015) Análisa de percepção dos extravistas estuarino costerios sobre o zoneamento da extração do caranguejo-uça (Ucides cordatus) e da madeira nos manguezais da RESEXMarinha Caeté Taperaçu, Pará, Costa Amazônica Brasiliera. Doctoral Thesis

Orians GH, Pearson NE (1979) On the theory of central place foraging. In: Horn DJ, Mitchell RD, Stairs GR (eds) Analysis of ecological systems. The Ohio State University Press, Columbus, pp 154-177

Pinheiro MAA, Hattori GY (2006) Relative growth of the mangrove crab Ucides cordatus (Linnaeus, 1763) (Crustacea, Brachyura, Ocypodidae) at Iguape, Sao Paulo, Brazil. Brazilian Archives of Biology and Technology 49:813-823

Pinheiro MAA, Fiscarelli AG, Hattori GY (2005) Growth of the mangrove crab Ucides cordatus (Brachyura, Ocypodidae). Journal of Crustacean Biology 25:293-301

Pinheiro MAA, Souza MR, Santos LCM, Fontes RFC (2018) Density, abundance and extractive potential of the mangrove crab, Ucides cordatus (Linnaeus, 1763) (Brachyura, Ocypodidae): subsidies for fishery management. Anais da Academia Brasileira de Ciências 90: 1381-1395

Piou C, Berger U, Feller I (2009) Spatial structure of a leaf-removing crab population in a mangrove of North-Brazil. Wetlands Ecology and Management 17:93-106

Pyke GH, Pulliam HR, Charnov EL (1977) Optimal foraging: A selective review of theory and tests. The Quarterly Review of Biology 52: $137-154$

Sandrini-Neto N, Lana PC (2012) Distribution patterns of the crab Ucides cordatus (Brachyura, Ucididae) at diVerent spatial scales in subtropical mangroves of Paranaguá Bay (southern Brazil). Helgoland Marine Research 66:167-174

Santos LCM, Pinheiro MAA, Dahdouh-Guebas F, Bitencourt MD (2018) Population status and fishery potential of the mangrove crab, Ucides cordatus (Linnaeus, 1763) in North-eastern Brazil. Journal of the Marine Biological Association of the United Kingdom 98: 299-309

Publisher's Note Springer Nature remains neutral with regard to jurisdictional claims in published maps and institutional affiliations. 